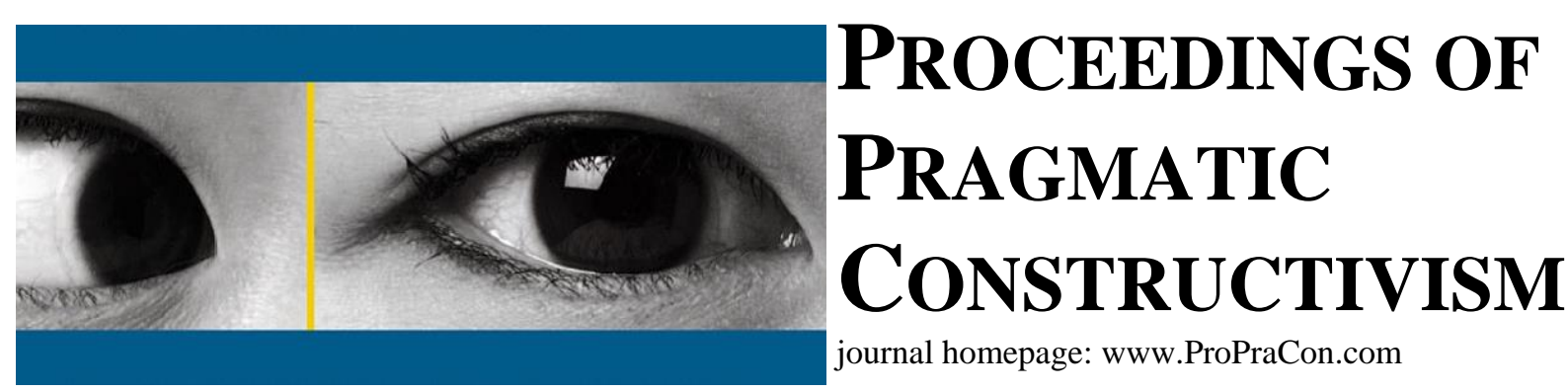

\title{
Occupational identities of management accountants: Situated identity regulation and work
}

\author{
Rafael Heinzelmann \\ Assistant Professor \\ NHH Norwegian School of Economics \\ Helleveien 30, 5045 Bergen, Norway; rafael.heinzelmann@nhh.no
}

\begin{abstract}
This paper investigates occupational identities of management accountants. It casts light on the identity process consisting of identity regulation, work, and self-identity, wherein organizational identity regulation is drawn to the fore. To theorize this process, the paper draws on Alvesson and Willmott's (2002) and on Giddens (1991). The accounting literature provides evidence that the role of accountants undergoes changes as a result of "new" technologies, competition, globalization and organizational managers' demands (cf. Granlund and Lukka, 1998). This paper takes a different route by focusing on how one organization fosters the controlling of occupational identities. I argue in line with others, i.e. Morales and Lambert (2013), that accounting practices are constitutive for occupational identities. However, this relationship is not straightforward. It is characterized by the tension between the actual work and the professional ideals. In order to safeguard a consistent identity accountants engage in identity work. The results show that the combination of different means of identity regulation creates a strong repressive framework for accounting practices reducing the freedom to act and judge as a professional. It contributes to a better understanding of how accountants' identities are subjected to control while simultaneously challenging the positive role associated with IT systems.
\end{abstract}

Keywords: Occupational identities; identity regulation; identity work; management accountants; biographical continuity; organizational control; accounting practices.

Acknowledgements: I would like to thank all interviewees, including various managers, accountants, directors, and academics. In addition, I am grateful to Martin Messner, Albrecht Becker, Silvia Jordan, Hanne Nørreklit, and Mihela Trenca for offering instructive comments on earlier drafts of this paper. I also wish to thank the participants of the Actor-Reality Perspective Conference 2013 in Aarhus, the Interdisciplinary Perspectives on Accounting Conference 2012 in Cardiff, the LSE AC 500 2012, as well as the Accounting Research Seminar, University of Innsbruck. Michael Bolling for providing help with the language. I also acknowledge funding from the Austrian National Bank (Project No. 12446).

\section{Introduction}

This article addresses occupational identities of management accountants. It contributes to the accounting literature on occupational identities in which the focus is on identity regulation. Prior studies have investigated the role of professional socialization (Ahrens and Chapman, 2000), tensions arising from the inconsistencies between professional ideals and the actual work (Morales and Lambert, 2013), as well as the impact of professional competition within organizations (Armstrong, 1985, 1987, Ezzamel and Burns, 2005). Extant research documents role changes of management accountants increasingly towards a more business-oriented function described as a business partner role (Burns and Baldvinsdottir, 2005, 2007, Goretzki et al., 2013). To this end, "trends" such as globalization, increasing competition, decentralization, IT-technologies, an increasing emphasis on customers and non-financial measures, and 
also accounting scandals are understood as major drivers for the establishment of this new business-inclined role model of management accountants (Burns and Baldvinsdottir, 2005, Granlund and Lukka, 1998, Vaivio, 1999, 2004).

On the one hand, only a few studies have addressed accountants’ identities explicitly (Becker et al., in Press, Haynes, 2006), and on the other hand, there is relatively little evidence pertaining to the influence of organizational settings. Given this paucity of prior research, the present article aims to shed light on how identity regulation takes place in the context of management accounting. By focusing particularly on the organizational control of identities, the article contributes to a better understanding about the ways in which occupational identities are shaped in organizational settings.

In order to develop this study, I mobilize Alevesson and Willmott's (2002) framework on identity regulation to show how organizations aim to control identities. The contribution this article makes to the literature on occupational identities is fourfold. First, it documents in detail the different means organizations employ to control and influence identities. More specifically, the study demonstrates which identity controls are mobilized, namely the adherence to standards, detailed guidelines, and the IT-system and the authority of social actors, i.e., the accounting group. Secondly, it reveals that the IT-system is central to accounting practices and identity work of accountants, casting light on accountants' sensemaking of their work, which becomes predominately governed by the IT-system. Thirdly, this study shows that in order to keep an identity aligned with professional ideals, accountants distance themselves from some accounting practices that are not in line with those ideals. To this end, "inconsistent" accounting practices are understood as a result of the IT-system's design. Fourthly, this article illustrates that having IT-systems available significantly impacts accountants and, more precisely, their freedom to act as professionals. As opposed to prior literature on the new role of accountants, this article finds that accountants have significantly less freedom with the increasing presence of IT-systems.

The article is based on a qualitative case study in an Austrian manufacturing company, investigating three different sites throughout Europe, in which most emphasis was put on how the organization seeks to control accountants' identities.

The paper is organized as follows. The next section provides an overview on the literature and related accounting literature. Section three introduces Alvesson and Willmott's (2002) theoretical framework and the notion of biographical continuity (Giddens, 1991). In section four, the research method and the material are introduced. Section five presents the case organization, section six addresses organizational and occupational identity regulation in the field of management accounting, section seven focuses on identity work, and section eight discusses and summarizes the major findings and conclusions.

\section{Literature Review}

In this section, the article discusses the extant literature related to the phenomenon of occupational identities, wherein four main streams of literature are identified, namely research on professional and organizational socialization of accountants, literature on professional competition, literature dealing with roles and tasks of accountants, and accounts concerning occupational identities. I outline the main lines of arguments and the findings and link them to occupational identities.

\subsection{Professional and organizational socialization}

Socialization has been a concern of the sociology of the accounting profession (Cooper and Robson, 2006). Accounting research primarily focuses on studying accountants working for elite workplaces such as the Big Four accounting firms. These studies indicate that the relationship between professional and organizational socialization are characterized by conflicts (Anderson-Gough et al., 2005, Coffey, 1993, 1994). For example, Anderson-Gough et al. (1998) found that organizational socialization into the Big Four accounting firms is significantly more influential for the professional identity of accountants than the socialization into the accounting profession provided by professional education. They illustrate how crucial the socialization into the accounting firms is due to the rising importance of client service that has come to dominate in many accounting firms and "banishing" public interests as a central theme in accounting firms (Anderson-Gough et al., 1998). In the same vein, Coffey $(1993,1994)$, who provides a detailed account on the socialization of training accountants, touches particularly upon how accountants establish their own professional identities while encountering conflicting sources of identity formation, being students and workers at the same time. She pinpoints that the "right habitus" is crucial to be successful and accepted as a colleague in the accounting firms (Coffey, 1993). These studies on the interface between professional and organizational socialization provide evidence for an increasing importance of work sites - the accounting firms - for accountants' identity formation. Accounting 
firms became increasingly subjected to commercial interests, downplaying professional codes of conduct or professional work ethics (Hanlon, 1998) and changing what is considered to be "appropriate" and "crucial” in terms of being an accountant. However, as these studies do not examine workplace-based accounting professionals such as management accountants, we have little knowledge on the socialization of accountants in "dispersed sites of accounting” (Cooper and Robson, 2006, 436).

\subsection{Professional competition between accounting and other bodies of expertise}

Some authors analyze competition between accountants and other professional groups. Armstrong (1985, 1987) argues that the significance of accountants compared to other professional groups in organizations can be explained against the backdrop of the importance of the capital market and the establishment of the joint-stock company. Accountants gain prominence while serving capital markets’ information needs, leading to the placement of many accountants in top management roles (Armstrong, 1985).

With the exception of Armstrong, a number of research papers have studied how accountants dominate other professional groups by means of implementing new accounting controls in organizations: Burns and Ezzamel (2005) study the implementation of economic value added and how this new tool strengthens the position of finance managers against buyers and merchandisers. Similarly, Carter and Crowther (2000) show how engineers become deskilled, marginalized, and lose their relevance in an electricity company after privatization, while accountants become regarded as important. In the same vein, Wittington and Whipp (1992) demonstrate intra-professional domination of accountants over marketing managers and Llewellyn (1998) over public sector managers. Others, for instance, Mueller and Carter (2007) and Kurunmäki (2004), notice an increasing adoption of accounting knowledge by other professional groups such as engineers and doctors. Consequently, accounting knowledge has become part of the professional expertise of other professional groups.

The literature on intra-professional competition helps to understand how accountants are positioned as professionals compared to other professional groups. Occupational identities are relational (Cooper and Robson, 2006), defining work and expertise in relation to or even in competition with other professional groups, which in turn makes intra-professional competition relevant for occupational identities.

\subsection{Roles and tasks of accountants}

There is some research in management accounting concerned with the roles and tasks of accountants in organizations. One major line of argument is that accountants' roles are subject to change towards a more business-inclined role (cf. Burns and Baldvinsdottir, 2007). This, a first and dominant strand of research, argues that the role of accountants changed from "bean counters" to "business partners" as a consequence of having, among others, IT-technologies in place in which the "counting” is done almost automatically. Consequently, accountants have more time to engage with operational processes and the "core” of the business (Azan and Bollecker, 2011, Burns and Baldvinsdottir, 2005, 2007, Goretzki, Strauss, 2013, Granlund and Lukka, 1998)

Other authors have explained accountants’ role change in terms of globalization, increasing competition and decentralization (Granlund and Lukka, 1998), the rise of customer orientation, and the emphasis on non-financial measures (Vaivio, 1999, 2004). Altogether, this strand of research understands the shift in accountants' role as a "positive" development, increasing organizational relevance of accountants and extending their role (Burns and Baldvinsdottir, 2007).

Another stream of literature has engaged in developing classifications of accountants' roles and tasks in organizations (Lambert and Sponem, 2011, Mouritsen, 1996). Based on a multiple case study, Lambert and Sponem (2011) develop a taxonomy of accounting functions: discrete, safeguarding, partner and omnipresent. In the same vein, Mouritsen (1996) demonstrates five of what he calls aspects of accounting departments' work - namely the bookkeeping, consulting, banking, controlling, and the administrator role.

One can summarize the different roles and tasks associated with management accountants drawing on the early contribution of Simon et al. (1954), distinguishing between scorekeeping, attention directing, and problem-solving. Whereas the first two are typically related to calculating, reporting, and controlling, the latter directs accountants' work towards decision-making and interaction with managers and other line functions, which is ascribed to the business partner role (Friedman and Lyne, 2001). Subsequently, different context-dependent roles of accountants co-exist, influencing accountants' occupational identities in different ways. 


\subsection{Occupational identities of accountants}

Few studies have explicitly addressed the issue of occupational identities of management accountants. In this context, Becker et al. (in Press) investigate changes in the identity of public accountants in the course of the introduction of accrual accounting and budgeting in German federal states, showing the link between accounting practices and changes in public accountants' identities. They characterize different “identities profiles,” namely the proven AOBB (Accrual Output-Based Budgeting) accountant, the ascendant AOBB accountant, the lukewarm sceptic AOBB accountant, and the outspoken sceptic AOBB accountant; providing evidence on the ways in which accountants construct their occupational identities when change happens (Becker, Jagalla, in Press).

Ahrens and Chapman (2000) analyze occupational identities of management accountants in the UK and Germany. They find differences in self-understanding regarding how accountants talk about their work, what accountants do, and how they are educated, theorizing these findings against the background of differences in the institutionalization of management accounting, education, as well as the societal prestige of accounting (Ahrens and Chapman, 2000). They introduce an important distinction between occupational identity, which can be juxtaposed with professional identity (Ahrens and Chapman, 2000). Whereas professional identity foregrounds professional socialization in the profession, essentially achieved through professional training as a chartered accountant, occupational identity draws organizational socialization and the role of the organization as workplace to the fore (Ahrens and Chapman, 2000).

Morales and Lambert (2013) study the alignment of identity work and management accounting practices. They report tensions between professional ideals, explicitly the business partner role and the actual work. Mobilizing the notion of “dirty work” (Hughes, 1951, in: Morales \& Lambert, 2013), they argue that accountants' identities are devalued through the devalued dirty tasks management accountants have to pursue. These so-called dirty tasks, i.e., bookkeeping, are inconsistent with the professional ideal of the business partner role (Morales and Lambert, 2013). Morales and Lambert (2013) mobilize the distinction between "unclean work" and "polluted work," whereby unclean work is incompatible but polluted work is consistent with the professional and desired role, observing a paradox: Despite the fact that the interaction with management is considered a prestigious dimension of the tasks consistent with the desired role, the practice of interacting with managers created more polluted work as accountants were treated as “dirty workers” (Morales and Lambert, 2013).

This article builds on the insights provided by the extant literature outlined above. Specifically, it draws on the notion of occupational identities, striving to study the significance of accountants' worksites on their occupational identities. As only a paucity of papers deals with identity in general and with management accountants in particular, it aims to contribute to the literature by responding to the following research questions:

\section{How does identity regulation in the context of management accountants take place in a specific organizational setting? And how do management accountants respond to identity regulation?}

\section{Identity regulation and the identity process}

Identities have encountered an increasing interest within management research in recent years (Alvesson et al., 2008, Ashcraft, 2013, Ravasi and Canato, 2013). Different approaches have been mobilized to study organizational identity, in which critical management studies (CMS) has been particularly concerned with the examination of identity. This paper draws on a framework emerging from CMS literature put forward by Alvesson and Willmott (2002). Unlike these authors, the focus of this paper is primarily on identity regulation in a specific organizational setting.

The authors argue that there is an increasing interest in the organizations and the society to manage people's identities, which is understood in light of efficiency claims aligned with managing the "soft side," namely people's feelings and emotions, in order to make them more intrinsically motivated and thereby increase economic output in organizations (Alvesson and Willmott, 2002). Against this background, the organizational dynamics of identity regulation seems to be a relevant topic of investigation both in theoretical and empirical terms.

In this context, occupational identity is not understood as a fixed, predefined, and testable concept, rather, it is thought of as a combination of the ways in which actors, such as accountants, are part of a specific professional group. They engage in sensemaking regarding their own professional role. In doing so, they engage in the identity process, which is based upon their practices consisting of numerous tasks and duties, role expectations, and professional ideals emerging from various sources such as the society, academics, professional associations, consultants and the organizations themselves. 
Alvesson and Willmott (2002) distinguish between identity regulation, identity work, and self-identity; each sphere is of equal importance in understanding identity and forming the identity process. Identity regulation prompts identity work, identity work re-works self-identity, and self-identity is responsive or resistant to identity regulation. At the same time, identity regulation influences self-identity, self-identity initiates identity work, and identity work informs identity regulation. The figure below illustrates the relationship between identity regulation, identity work and selfidentity:

Figure 1: The interplay between identity regulation, identity work, and self-identity (Alvesson and Willmott, 2002, 627).

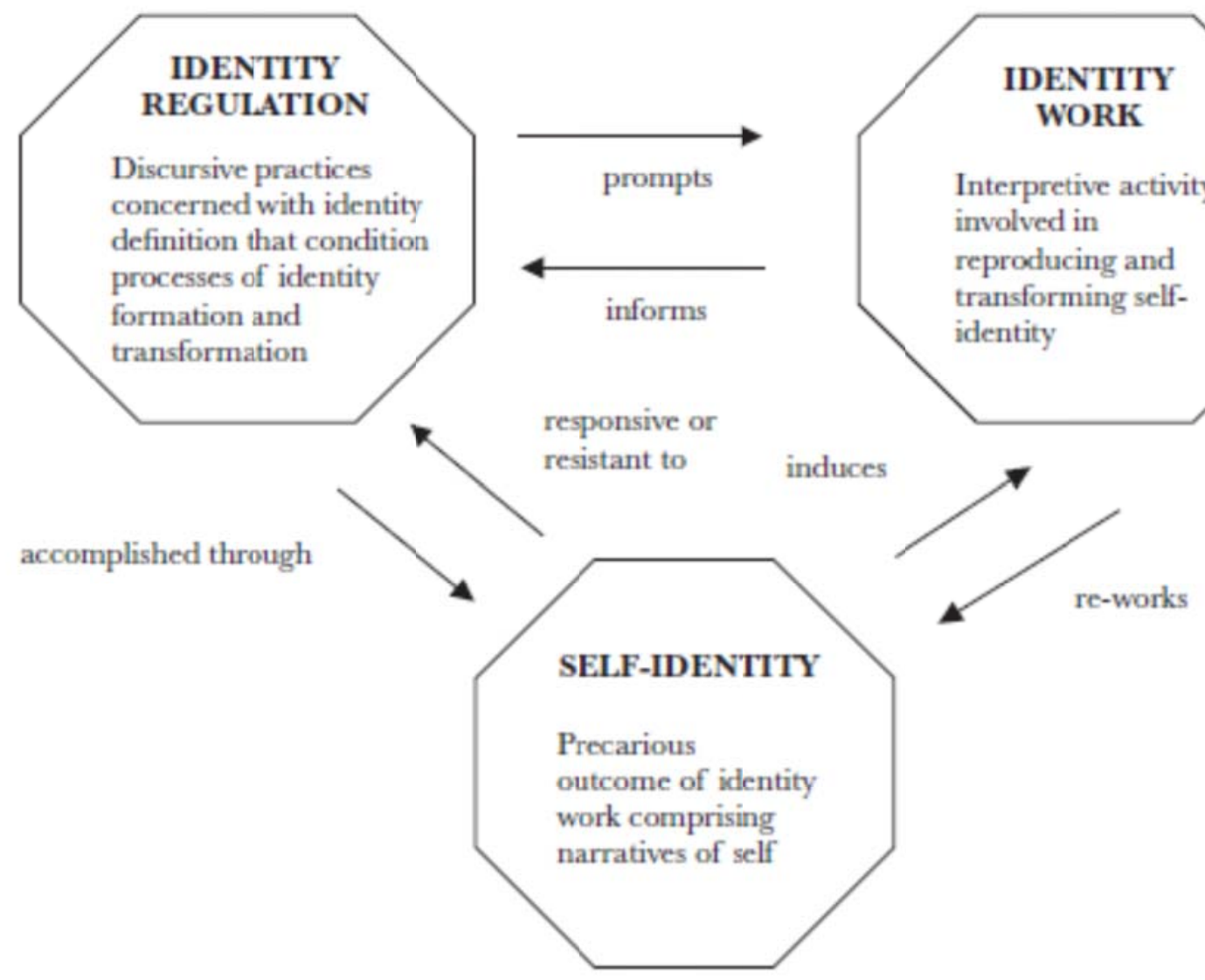

Identity regulation offers ideals of what it means to be a professional, and these ideals are translated into narratives of self-identity (Alvesson and Willmott, 622). Thus, people in organizations and in professions simultaneously influence and are governed by identity regulation. In this context, identity regulation is defined as follows:

“... an activity which encompasses the more or less intentional effects of social practices upon processes of identity construction and reconstruction” (Alvesson and Willmott, 2002, 625).

Professionals are the medium through which such identity constructs are promoted or actively rejected, and they are also the outcome regarding the effects of such identity regulation attempts. Identity regulation is persuaded by the means of induction, training and corporate education via corporate communications, etc. (Alvesson and Willmott, 622). Regulating identity fosters the construction of 'we' regarding the occupational identity. Socio-ideological control is seen as a part of identity regulation, where socio-ideological control is described as the “...efforts to persuade people to adapt to certain values, norms and ideas about what is good, important, praiseworthy, etc. in terms of work and organisational life” (Alvesson and Kärreman, 2004, 426) and can be distinguished from technocratic control, which places emphasis on norms, rules, procedures, the formalization of tasks, etc. The paper mobilizes this distinction in order to have an analytical instrument to study organization-based identity regulation.

Drawing on identity regulation, people engage in identity work. Identity work is important for the reason of having concomitant stabilizing and weakening effects on the self-identity. Sveningsson and Alvesson (2003) present identity work in the following way: 
“...identity work refers to people being engaged in forming, repairing, maintaining, strengthening or revising the constructions that are productive of a sense of coherence and distinctiveness. Identity work may either, in complex and fragmented contexts, be more or less continuously on-going or, in contexts high on stability, be a theme of engagement during crises or transitions"(Sveningsson and Alvesson, 2003, 1165).

In other words, identity work "re-works" identities in order to achieve biographical continuity. Subjects are not passive "consumers" of identities created by organizations (Alvesson and Sveningsson, 2003). On the contrary, identities are evaluated by individuals in "...specific events, encounters, transitions, experiences, surprises...” (Alvesson and Willmott, 2002, 626).

Identity work has also been described as a struggle (Alvesson, 2010) to answer the question "Who am I?" (Sveningsson \& Alvesson, 2003, 1164). This is in line with Giddens (1991), who argues that identity presumes the ability to distinguish $\mathrm{I} / \mathrm{me} / \mathrm{you}$ as well as to respond to this question. As regards occupational identities, these scholars understand identity work as the active engagement in making sense of the job, which is impacted by various societal, organizational, and professional influences that produce tensions and inconsistencies in the occupational identity construct. To keep a particular narrative going (Giddens, 1991, 54), which enables biographical continuity, identity work is conducted in a way that is contingent upon life history and filters out major tensions and inconsistencies (Alvesson and Willmott, 2002).

In a nutshell, identity work can be defined as interpretive activity "working on" self-identities. It is an important part of identity because it re-works accounts of self and informs identity regulation. This constant process of creating, forming, adapting, and changing over time and space makes it possible to achieve biographical continuity (Giddens, 1991) by means of relating one's identity to a few significant events which fit into the understanding of self.

Self-identity is understood as "the precarious outcome" (Alvesson \& Willmott, 2002) of identity work or as "the articulation of self" (Giddens, 1991, 53). Self-identity assumes first and foremost the reflexive awareness of actors and is constituted by continuity. Consequently, self-identity aims to maintain a "protective cocoon" (Giddens, 1991, 53) across time and space. The protective cocoon is the construct of self “... which 'filters out,' in the practical conduct of day-to-day life, many of the dangers which in principle threaten the integrity of the self" (Giddens, 1991, 54), enabling the achievement of biographical continuity across time and space.

A pertinent property of self-identity is that it is robust and fragile at the same time. On the one hand, 'robust' describes its ability to remain stable in spite of tensions arising from changes in time and space (ibid.). On the other hand, self-identity is fragile because the particular description of the self is one of several stories about the development as self (Giddens, 1991, 55). Subsequently, tensions, inconsistencies, and changes can evoke adaptations of selfidentities. Unlike passive constructs, which are only an outcome of the environment, self-identity actively shapes its environment. Biographical continuity, which is the main implicit aim of an individual's identity work, can imply that professionals make a distinction between professional ideals and inconsistent accounting practices, distancing themselves from the inconsistent elements and ascribing them, e.g., to the IT-system.

\section{Research method and material}

This article is based on a qualitative research methodology, drawing, on the one hand, on a single case study in a manufacturing company and, on the other hand, on interviews with employees of various professional institutions. The case study has been conducted in an Austrian manufacturing company, Chipboard Ltd., with subsidiaries in many European countries, wherein fieldwork was done in the Austrian headquarters, as well as in the UK and French subsidiaries. The empirical material was collected from May to December 2010 at Chipboard Ltd. The material consists of semi-structured interviews with accountants and managers ranging from departmental managers to financial and technical directors. Additionally, internal documents such as handbooks, presentations, other strategic documents, as well as publicly available data were collected. Fieldwork consists of four visits to the headquarters and two visits to the French and British subsidiaries. As these three cultural contexts are known for their differences regarding management accounting (Ahrens, 1997, Armstrong, 1987, Bourguignon et al., 2004), it seemed appropriate to talk to different groups of accountants in Chipboard Ltd. in order to develop a better understanding of how identity regulation works in these various organizational settings.

In total 18 interviews were conducted, recorded, transcribed, and analyzed (Please see the appendix on the empirical material and the interview guidelines). In addition, the researcher interviewed and collected material on professional institutions in management accounting in the UK and German-speaking countries by interviewing executive directors, directors of education, and two British academics who have close connections to professional 
institutions. The reason for including these interviews in the study is to develop a better understanding about the professional socialization of management accountants in the UK and Germany and to gather evidence on how professions seek to influence accountants' identities and how these identity regulation attempts are visible and influential on an organizational and individual level. Specifically, I investigated the Chartered Institute of Management Accountants (CIMA), the Institute of Chartered Accountants of England and Wales (ICAEW), the Controller's Academy (CA, Controller Akademie), as well as the Austrian Controller's Institute (CI formerly known as ÖCI, Österreichisches Controller-Institut ${ }^{1}$. In total, seven interviews were conducted, recorded, transcribed and analyzed (please see again the appendix for details).

Data analysis and conceptualization were iterative (Glaser and Strauss, 1968), going back and forth between the empirical material, theory, and relevant literature. The analysis of the material was, in particular, driven by the attempt to develop an understanding of how the organization strives to control accountants' identities. Furthermore, I aim to shed light on how accountants exercise identity work (making sense of identity regulation attempts) and how the relationship between accounting practices and occupational identities become mutually constitutive. To this end, the paper mobilizes Alvesson \& Willmott's (2002) framework on the micro-organizational context of specific organization in Chipboard Ltd. Concomitantly, the paper examines the role of professions in order to account for how the broader identity discourse is translated into the organizational one.

\section{Chipboard Ltd.}

The research site, Chipboard Ltd., is a manufacturing company producing wood products for the European market. It is family-owned and not listed on the stock market. The headquarters are based in Austria. The group has about 6000 employees and comprises 17 production plants and 20 sales offices at the time of writing. All production plants and sales offices are located in Europe. The company's main product is chipboards for the furniture industry.

Over the past five years, the company has undergone remarkable changes in its governance structure, in financing its business, and in the number of sites operating in different countries. Chipboard Ltd. is currently run by three professional management employees: a Chief Financial Officer who is also the speaker of the executive board and responsible for human resources, a Chief Production and Technology Officer, and a Chief Marketing and Sales Officer. Traditionally, the company was always managed by members of the owner's family. Though the owner's family is no longer represented in the executive board, the family still influences strategic decisions via the supervisory board.

Chipboard Ltd. was launched in the 1960s. In the last ten years, it has seen accelerated growth through acquisitions and the construction of new plants in various European countries. Quite recently, Chipboard Ltd. has taken over a Russian and a Turkish competitor in addition to putting a new plant in Romania into operation. The changes in the management have yielded more growth in the return on sales, EBITDA, the number of employees, and investment volume as well as the company's increased presence in other European countries. Internationalization, the accelerated growth, and the new management significantly influenced the way in which the company is managed and organized. Namely, the organizational design, the organizational procedures, and the official company language were subjected to changes. For instance, staff functions for different functional units, such as accounting, production, logistics, and so forth, were created at the headquarters and handbooks were translated. Also, the financing of the business underwent severe changes. Chipboard Ltd. started to finance some of its business activities with long-term bonds from the capital market, so it now publishes more detailed annual reports to fulfill capital markets requirements.

One has to notice that one peculiarity of Chipboard Ltd. is that all its plants are located in rural areas, where the main resource, wood, is readily available. Even the headquarters, which consists of the administrative offices and the company's first production plant, is situated in a small city. Historically, the case organization has always owned plants in Austria. Its growth strategy has always been either the acquisition of companies and plants or the building of new manufacturing units. The subsidiary in the UK was the first purchase outside of Austria, followed by plants in Germany and France. Whereas the UK plant was independent before it became part of the group, the French plant was already part of the grou

The location of production facilities in the countryside, close to forests, shapes the company’s role in the region and is also crucial to its corporate culture. First, in all three regions, Chipboard Ltd. is the biggest employer within a 20kilometer radius. The company's main competitors are not far away, though, which makes each of these regions a kind of a "wood cluster." Second, the corporate culture can be characterized as down to earth, long-term oriented, and conservative. The corporate culture, together with the location of its plants, hinders the recruitment efforts of Chipboard Ltd. in terms of recruiting highly skilled managers, accountants, and engineers.

The ÖCI has been renamed in 2013. Now, it is called Controller-Institut abbreviated with CI. 


\section{Practices of identity regulation}

Micro practices of identity regulation are a part of broader professional discourses, which influence micro practices of identity regulation by providing, for example, favorable professional role models. In other words, micro practices of identity regulation are the attempts of organizations, etc. to influence on members' occupational identities. Specifically, I strive to show different forms of identity regulations by juxtaposing professional discourses about the role of accountants, for instance, with organization-based identity regulation. As the main emphasis of the article is on the organizational level of identity regulation, the social practice of directing management accountants' professional selves is investigated, wherein at which identity regulation is deeply rooted in intervening in the process of identity construction and reconstruction (Alvesson and Willmott, 2002).

\subsection{Role models}

Role models are conveyed as idealized descriptions of professional roles, in this case, the roles of management accountants. Notwithstanding, the literature indicates a normalization of role descriptions towards the business partner or business analyst role (cf. Burns and Baldvinsdottir, 2005), particularly regarding the roles ascribed by professional institutions, where there are still noticeable differences in the way in which professional bodies define roles. By investigating CIMA, ICAEW, CA, and ÖCI, the paper finds three idealized roles: finance leaders, real life accountants, and accountants as sparring partners of the management, where the latter two roles overlap to some extent.

\subsubsection{Finance leaders}

The Institute of Chartered Accountants of England and Wales (ICAEW) developed a so-called finance framework, identifying key drivers and main finance activities in accountants' work. It describes environmental, accounting, and organizational drivers and identifies accounting, management \& control, strategy \& risk, compliance, and funding as major activities of chartered accountants. ICAEW puts most emphasis on training the future leaders in the finance function. In doing so, ICAEW claims to educate and license future CFOs and CEOs. Likewise, this is important for management accounting, as ICAEW understands the whole territory of accounting as their professional jurisdiction and as ICAEW trained accountants quite commonly work in what they call "business," as opposed to accounting practice. Whereas accounting practice refers to Big Four companies or other accounting firms, business is working in industry, etc., outside of the classical monopoly of chartered accounting bodies. The role of the chartered accountant is explained in the following manner:
"...so we have developed this idea of what a finance function does. And so it is very broad in terms of the basics of accounting and control and the financial regulations, managing performance which you might expect that the management accountant carries out. ... managing the relationship between the investors and funders, strategy and risk management. We very much see them [the finance function] as an interconnected and overlapping function” (Director of Research, ICAEW).

Financial leadership is regarded as a key attribute of ICAEW graduates. It is particularly stressed that ICAEW has the highest number of finance directors, CEOs, and partners among the FTSE 100 companies, attesting to the ICAEW's claim to the financial elite. In line with this, ICAEW sees itself as the worldwide leader and most prestigious accounting body. The ideal-type role of the finance leader is presented broadly, ranging from standard accounting tasks to managing fundraising. ICAEW's self-concept is based on the understanding of being the prestigious, elitist, and legitimate institution for educating and licensing accountants for the entire field of accountancy, including financial, management accounting, and auditing.

This picture of self is derived from a royal charter for accountancy. Consequently, ICAEW exhibits public, legal, and workplace jurisdiction for accountancy. When it comes to drawing the ideal-type role of the finance leader - which is vague, broad, and unspecified - ICAEW employs an esoteric concept of self serving the public interest (Abbott, 1988). ICAEW is relevant for identity regulation of management accountants as ICAEW is one of the key professional bodies for educating and licensing accountants also working in a management accounting. As opposed to the ICAEWascribed role of accountants (the finance leader), CIMA claims to train and license real-life accountants. 


\subsubsection{Real-life accountants}

CIMA, the Chartered Institute of Management Accountants, makes the claim that they are the only accounting body in the world exclusively dedicated to training accountants in business, the so-called real-life accountants. The real-life accountant is constructed as active and impactful, a role which is driven by the needs of companies.

“...accountants are moving out to sit together on a floor and moving into the business to work with the engineer, the marketers to partner them in successful decision-making. No, our research indicates that a lot of businesses want that to happen..." (Director of Education, CIMA).

CIMA evolved from the Institute of Cost and Work Accountants, changing in role from a main emphasis on costs to broader responsibilities in light of globalization and increasing dynamics in business life. Its royal charter for management accounting provides CIMA with the legal jurisdiction in this field of accounting. In the public and workplace arenas, the jurisdiction is shared with ICAEW and other accounting bodies in the UK. CIMA discriminates between real-life accountants and auditors:

"...of course auditors are looking at the business from the outside in and then of course really never get to grips with the DNA of the business" (Director of Education, CIMA).

Accountants working for accounting firms are categorized as auditors by CIMA. The role model of real-life accountants is developed in contradiction with the auditor role. The idealized role of real-life accountants ascribed to CIMA certified accountants is characterized in a way similar to the business partner role.

\subsubsection{The sparring partner role}

Both German-speaking bodies, namely CA and ÖCI, mobilize the idealized role of the sparring partner, ${ }^{2}$ where the accountants are characterized as the sparring partners of the management, the conscience of companies, and as internal consultants:

"We call the controller sparring partner. Well we put it more hands-on, we similarly say that he is the economic conscience in companies" (Director of Education, CA).

Starkly in line with this is the business partner role, which is part of extensive debates within these professional accounting bodies. Particularly, the German Controller Academy underlines its leading position in advocating and teaching this role from the early beginnings:

"What does it mean to me to be a controller? These are the early pictures of Deyhle (the founder of CA) the pilot or the navigator. Until today, this can be signed. Nowadays this is frequently called business partner. This business partner supports with its service competence the manager, the leader in each position... this basic understanding of controllers as business partners and sparring partners has been very early formulated and postulated by Mr. Deyhle” (Director of Education, CA).

The controller is understood as an accountant strongly involved in business processes and part of the management team. As the ÖCI and CA do not exhibit legal jurisdiction in the sense of Abbott's systems of professions (Abbott, 1988), their professional arena for claiming jurisdiction is limited to the workplace and public arenas. CA and ÖCI are strongly recognized and well-regarded in the practitioner-community - one could argue that they exhibit workplace jurisdiction for management accounting.

Remarkably, all management accounting bodies draw on the business partner ideal-type role, in contrast to the ICAEW, which strives for the finance leader role. The case company, Chipboard Ltd., does not rely on a specific role model for accountants, but as shown later, accountants use the business partner ideal in order to pursue identity work. The handbook for controllers, which is the main reference point for management accounting work within Chipboard Ltd., only defines in an abstract way the term Controlling, the German term for management accounting:

"Controlling provides the management with information that is necessary for their decision-making. It co-ordinates, monitors and optimizes all operations within the company. For this purpose, the

$2 \quad$ It is important to note that CA and ÖCI are strongly engaged in the ICV (Internationaler Controller Verein) and the International Group of Controlling (IGC). These organizations are non-profit companies aiming to advance the idea of Controlling. In addition, CA and ÖCI are not considered direct competitors. 
consumption of production factors as well as the company's activity performed is recorded. In addition to the documentation of effective results, a second main function of the Controlling is strategic planning. Discrepancies are detected by comparing effective figures with planned figures. It is through these variance analyses that one can interfere effectively with the company's activities. Income statements, like the contribution margin accounting, are needed to control the profitability of single divisions as well as of the entire profit centre" (Handbook for controllers).

This abstract way of defining management accounting and the work which accounting involves stands in contrast to the role models provided by the professional bodies reported earlier. In terms of writing style, the handbook for controllers reflects the way in which German-speaking textbooks write about management accounting. The role associated with Controlling is abstract but at the same time hands-on, delineating the main tasks of management accountants. Chipboard Ltd. does not revert to role models provided by professional bodies. As ICAEW and CIMA focus on developing a unique role model by relying on their jurisdiction, Chipboard Ltd. is more concerned with abstracting management accounting, distinguishing management accounting from financial accounting and specifying tasks and duties of management accountants.

\subsection{The distinction - contrasting “different" accountants}

Chipboard Ltd. distinguishes between different types of accountants, where the main distinction is based on which purposes the accounting information is produced for. Consequently, management accounting is separated from financial accounting. Whereas management accounting information is predominately produced for internal decision-making purposes, financial accounting fulfills the reporting rules and requirements. This separation is typical for Germanicspeaking companies having a long tradition of using different systems for financial and management accounting, also referred to as the two-ledger system, compared to the one-ledger systems which are used, for instance, in the United Kingdom (Zirkler, 2002).

Having two separate ledgers subjects accounting departments to the splitting of the accounting function into two separate groups. Accountants within Chipboard Ltd. are organized into the financial reporting / consolidation group and into the management accounting group. Only the UK subsidiary's integrated accounting unit prevailed for a long time. The financial director in the UK describes the way in which Germanic accounting teams are organized in the following way:

"In Austria and in Germany you have a head of accounting [Rechnungswesenleiter]. And there is a strict separation in financial accounting, and then there is a controller. The head of accounting has a background either in Controlling or financial accounting” (FD, UK).

Only recently has UK-accounting become restructured to be more in line with the Germanic model comprising two separate accounting teams. Prior to this, accountants had much broader roles:

"Well, in the department we are in a sort of transition. Things are changing. For the last few years we were slightly different from other Chipboard plants in Austria or France, where Controlling and finance are clearly separated functions. Here it is more combined. The other accountants and I have really played much broader roles than perhaps the other Chipboard employees [in accounting]. So for the end of month work, for instance, we produced the monthly profit and loss statement, the income statement, and we carried out some finance functions" (Management accountant, UK).

On a more general level, management accountants are considered to be more important than financial accountants within Chipboard Ltd. Management accounting information is constructed to be decision-useful, close to operations and the actual business. One of the senior controllers reflects on the status of controllers vs. financial accountants as follows:

"For financial accountants that wasn't always fun. The focus has always been on Controlling, Controlling, Controlling. And the controllers are involved in everything. The financial accountant is only involved once a month in order to make the monthly income statement...” (Senior controller, Austria).

Separating accounting has a long tradition in German-speaking accounting academia and practice. Chipboard Ltd. exemplifies this separation in which the two-ledger system and its consequences for having two different types of accountants remains largely unquestioned by practitioners. Germanic professional bodies, namely the Controller Akademie, seems to reinforce this distinction: 


\begin{abstract}
"We propagate a clear functional separation between both spheres [management accounting and financial accounting] in terms of depth of knowledge in both spheres. So to say, that a financial accountant must know every detail in IFRS. In contrast, the controller must be able to understand and manage the implications, the consequences of IFRS reporting to management accounting and control. ...You can't manage a company with IFRS. You can only manage with forward-orientated information from management accounting. And the controllers have to manage the transfer between financial and management accounting information in a 'proper' way" (Director of Education, CA).
\end{abstract}

The quote above illustrates the separation discourse within German-speaking practitioners and the academic community, with which both communities are still strongly intertwined (Messner et al., 2008). The implementation of IFRS / IAS and the internationalization of German-speaking companies subjected the academic accounting community to discussions about the impact of these developments on the Germanic two-ledger accounting system. Many academic papers have concluded that these changes will have an impact which most likely will lead to a closer integration of financial and management accounting (Simons and Weißenberger, 2008, Trapp, 2012). Whereas the academic community has predominantly focused on the technicalities, professional bodies, as one major player within the practitioners community, are more concerned with the role implications. In this context, the role of the Biltroller ${ }^{3}$ combining financial and management accounting in one person is debated:

"When I first heard this notion Biltroller at Metro [large German retailer] ...it's an artificial notion for me, bringing about the risk that Controlling is reduced to financial statements. That's the risk. But on the other hand, we - the controllers - increase their importance because we are providing important information from management accounting which are now of crucial importance for the preparation of financial accounting statements" (Director of Education, CA).

In particular, professional bodies are very keen on constructing and upholding the controller's role as business partner, or, that is to say, as sparring partner of the management, as well as more prestigious and impactful than the role of financial accountants. This can be interpreted against the background of the workplace jurisdiction held by the Germanic bodies in management accounting. In addition, management accounting education provided by universities and professional bodies does not necessarily include a considerable amount of financial accounting (Ahrens and Chapman, 2000). For instance, the so-called five-stage program taught by the Controller Akademie and the ControllerInstitut encompasses only the basics of double-entry bookkeeping. This stands in contrast to CIMA's approach, in which financial accounting is one of the three main learning pillars in the Chartered Management Accountant training:

"We have three learning pillars and financial accounting is one of those three. So, we see it as important. I think it is true to say that the skill set that we want to focus on is one of emphasis on the interpretation of financial accounting information and the communication of it to non-finance people in the organization. However, our members and our students can prepare sophisticated financial accounting statements that are IFRS consolidated” (Director of Education, CIMA).

CIMA holds public, legal, and workplace jurisdiction for management accounting in the UK. Thus, differentiating it from financial accounting, and particularly from ICAEW, is still a major concern of CIMA:

"Obviously, the financial accounting is a very exact science. Management accounting isn't because life isn't. [...] so we have evolved through costs and works to management accounting and I think alongside that evolution of businesses was in parallel” (Director of Education, CIMA).

In line with the role model of real-life accountants, CIMA's professional ideal is seen as a parallel development to the changes in the business environment. Professional bodies seem to advocate for the business-inclined role of management accountants. Chipboard Ltd. does not rely on the ideal role of the business partner, rather, it draws on an abstract academic distinction from financial accounting rooted in the Germanic accounting tradition. One major organizational concern is the distinction from financial accounting in terms of controller role and the IT/ERP system.

To some extent, this reflects the discourse taking place within the practitioners and academic community. However, particularly interesting is that both Chipboard Ltd. and the Controller Akademie see management accounting as having

Biltroller stems from BI for Bilanz, the German notion for balance sheet, and the notion of the occupational role, the Controller. The Biltroller first emerged as a new role model for accountants at Metro. Metro is one of the largest German retail groups. In the following years, Metro started to advertise jobs in accounting by referring to the new role of Biltroller. 
the leadership role in accounting instead of establishing an identity for the whole field of accountancy. On the one hand, the separation logic is deeply rooted in the Germanic accounting tradition, which is rather unquestioned and unchallenged. In the context of Chipboard Ltd., a strong identity for controlling can be juxtaposed with a less powerful financial accounting, wherein neither the strong role of management accounting nor the weaker role of financial accounting is debated, reflecting the German-speaking tradition.

On the other hand, the Controller Akademie, as a professional body specialized in management accounting, has a strong interest in positioning management accounting as something distinctively different. In particular, the workplace jurisdiction held by the CA makes it even more important to stress the importance of management accounting for decision-making and leadership.

\subsection{Socio-ideological controls}

In German-speaking countries, the term Controlling is used to describe what is meant to be management accounting in the Anglo-Saxon world. However, there is some common knowledge shared among professional bodies, academics, and practitioners, that Controlling should be conceived of as something that goes beyond management accounting (Messner et al. , 2008). Chipboard Ltd. builds on this view and mobilizes the notion of Controlling across all language barriers in all subsidiaries. Most emphasis is put on input controls, called "the consumption of production factors" in the handbook for controllers, strategic planning, variance analysis, as well as the appraisal of profitability on different levels based on the contribution margin accounting technique. The handbook for controllers sets out the main tasks comprising management accountants' work. The following table compares activities considered a part of management accounting by Chipboard Ltd. and the International Group of Controlling (IGC):

Tab. 1: Activities in management accounting

\begin{tabular}{|c|c|c|}
\hline & Chipboard Ltd. & $\begin{array}{l}\text { The IGC Process model of Controlling (IGC, } \\
\text { 2011) }\end{array}$ \\
\hline $\begin{array}{l}\text { Overall } \\
\text { Activities }\end{array}$ & Providing information for decision-making & $\begin{array}{l}\text { Setting objectives } \\
\text { Planning } \\
\text { Control }\end{array}$ \\
\hline Main Activities & $\begin{array}{ll}- & \text { Consumption of the production factors (Input } \\
& \text { controls) } \\
\text { - } & \text { Documentation of effective results } \\
\text { - } & \text { Strategic planning } \\
\text { - } & \text { Variance analysis } \\
\text { - } & \text { CO-based income statements } \\
\text { - } & \text { (cf. Contribution margin accounting) } \\
\text { - } & \text { Control of profitability } \\
\end{array}$ & $\begin{array}{ll}\text { - } & \text { Strategic planning } \\
\text { - } & \text { Operational planning and budgeting } \\
\text { - } & \text { Forecasting } \\
\text { - } & \text { Cost accounting } \\
\text { - } & \text { Profitability analysis } \\
\text { - } & \text { Management reporting } \\
\text { - } & \text { Project and investment Controlling } \\
\text { - } & \text { Risk management }\end{array}$ \\
\hline $\begin{array}{l}\text { Additional } \\
\text { Activities }\end{array}$ & $\begin{array}{l}\text { "It coordinates, monitors and optimizes all operations } \\
\text { within the company" (Handbook for controllers) }\end{array}$ & $\begin{array}{l}\text { Controlling for specific purposes, consulting, } \\
\text { leadership, continuous development of the } \\
\text { organization, its processes, instruments, and systems }\end{array}$ \\
\hline
\end{tabular}

The combination of normative elements represented by the handbook for controllers, the concept of Controlling and a number of other guidelines, the IT system SAP, as well as the accounting group contribute all to the form of identity control within Chipboard Ltd. Specifically, the use of the concept of Controlling in conjunction with the accounting group can be understood as a socio-ideological form of control (Alvesson \& Kärreman, 2004). In contrast to technocratic control, which is represented by the SAP system and various normative sources, e.g., the handbook for controllers, socio-ideological control aims to persuade people to adapt certain norms and ideas (Alvesson \& Kärreman, 2004).

The concept of Controlling is understood as a socio-ideological norm at Chipboard Ltd. It encompasses, on the one hand, the broader discourse of Controlling set by academics, various influential practitioners, and the professional organizations, but on the other hand, it provides an organization-specific conceptualization of management accounting. The accounting group and its subdivision for management accounting sets the agenda on a group level. The concept of Controlling is linked to good professional conduct becoming particularly evident in accountants' identity work practices while at the same time remaining linked to the SAP system.

Drawing on technocratic and socio-ideological forms of control allows Chipboard Ltd. to construct a "we" in management accounting, wherein this "we" is driven by the major standardization concern that "everybody speaks the 
same language” (Handbook for controllers). The accounting group plays an important role in identity regulation by reason of its responsibility to develop rules, guidelines, and templates. In addition, the accounting group is in charge of the rollout of new tools and controls the adherence of standards that are quite strict. For instance, every new cost center has to be approved by the accounting group, which also then takes on the role of teaching accountants throughout the group how the systems are used. Socio-ideological forms of identity regulation are dominated by the accounting group as a social actor and the concept of Controlling.

In addition, the IT system in use has a major impact on accountants. The SAP system became an important reference point and part of the practice repertoire, in other words, one of the resources in order to perform accounting. The implementation of SAP changed the way in which management accounting is practiced and how it is talked about:

"Today we are more dependent on IT, especially due to all these programs and possibilities of analysis. This has become daily work for us. But we are dependent, because this is our toolbox. Previously, we just used Excel sheets, and at the time we were less dependent in a way. And I think that the information in the past wasn't wrong. You can't say that everything is more correct or better with SAP" (Plant Controller, Austria).

The SAP system took away the independence of management accountants' work, which has been an important identity giver, and replaced it with system dependence, a large number of standards, and templates. Indirectly, management accounting work is understood as independent craft work having lost its independence regarding knowledge base. Additionally, management accounting information and work became predominately associated with SAP. Accountants also lost their jurisdiction over costing information to the SAP system, which only increased their dependence on the system.

The SAP system, simultaneously, changes the language mobilized to talk about accounting-related things, exemplified by the way in which the handbook for controllers outlines the connection between financial accounting and Controlling:

"Controlling (CO) and Financial Accounting (FI) are represented within the SAP system as independent application components. These two applications communicate regularly with each other, so all the data relevant for cost calculation flows automatically from financial accounting to Controlling, and costs and revenues are allocated to different $\mathrm{CO}$ account assignment objects (e.g. cost centres or orders). The relevant accounts of the financial accounting are handled as cost elements within Controlling. Through this, the values obtained by Controlling and by financial accounting can be compared and adjusted" (Handbook for Controllers).

Accounting became linked to the subsystem within SAP, where the CO-module is designated for management accounting and financial accounting is represented by the FI-module. Accounting became a matter of SAP processes, i.e., the way in which FI objects are translated into CO cost elements. The language is dominated by SAP terminology and the Germanic accounting tradition became visible in this excerpt of the handbook for controllers. This way of talking about accounting is mobilized during interviews and conversations, exemplified by the head of the accounting group who verbalizes the link between financial and management accounting:

"The transformation from FI to CO [SAP process] is the most important. That means if there are differences, the controller has to talk to the financial accountant, and they have to discuss the differences. They have to agree and talk to each other...” (Head of the Accounting Group, Austria).

This domination of a technocratic, SAP-inclined language in accounting is reflected in the language mobilized by accountants. Moreover, in the course of the SAP implementation, Chipboard Ltd. became obsessed with guidelines, templates, and tight controls on how management accounting work should be done across the group. The group "normalized" and standardized management accounting work throughout by drawing mainly on a set of management accounting practices inscribed in the CO-module, fitting the way of conceptualizing and understanding accounting at the headquarters.

Precisely, Chipboard Plc. rolled out a number of highly standardized templates coming along with new guidelines having to be adhered to by all accountants. This set of "new" techniques included a number of idiosyncratic Germanic accounting techniques, namely imputed costs, detailed contribution margin accounting, and flexible standard costing (see Heinzelmann, 2013a, b, for a detailed account on the relationship between idiosyncratic Germanic techniques and SAP). The SAP system limits the professional choice and judgment of accountants to the standardized techniques inscribed in the system. 
"SAP brought everything together - standards, new policies, and now the information we produce is centralized. So, there is no scope anymore for "creative accounting” (Management Accountant, UK).

Consequently, the space for creativity and professional judgment in accounting, illustrated by having the right to select the appropriate technique in order to match managers' information needs, is replaced by guidelines, standards, and techniques inscribed in the SAP system.

"You would not be allowed to have different! (sic) We have to go with very much what they (the headquarters) do. We use the same transactions in SAP. The costs of goods need to be comparable. We would all have to use the same basis for costing rather than choose a different one which is more UKfamiliar” (sic) (Management Accountant, UK).

These "tight controls" of accounting practices established by the headquarters work as strong identity regulation among the accountants. The freedom to act and judge as a professional within a certain scope of action affects the accountants' occupational identities. What can be observed at Chipboard Ltd. is the combination between technocratic and socioideological forms of control, constituting a powerful infrastructure for identity regulation.

\section{Identity work of accountants}

Accountants engage in identity work in order to achieve coherence, continuity, and distinctiveness of their occupational identity constructs by forming, repairing, maintaining, strengthening, and revising their occupational identity (Alvesson and Willmott, 2002, Sveningsson and Alvesson, 2003). One important reference point for accountants is the status of accounting in the organizational setting since identity is relational (Lamont, 1992). In other words, people - in our case, professionals - position themselves against other professional groups, thus engaging in intra-professional relations. At Chipboard Ltd., there seems to be a shift from a main emphasis of production towards "numbers":

"When I think back to when I started at Chipboard Ltd. 12 years ago, production was the most important thing. The moulding press had to run and everything else was secondary. This has changed significantly in recent years. The trend is more towards numbers - Controlling. Numbers explain where we are, how we are positioned, where we make money and where we don't. This has certainly been a radical change. Nowadays Controlling is more important than production. This is my personal view! Maybe this is in line with changes in our executive board over the last few year, now finance is much more central and probably that is wise" (Technical Director, UK).

In line with this view from a perspective of professional competition, accounting is seen as value-adding activity. In particular, management accounting and cost accounting work is valorized at Chipboard Ltd. According to a senior accountant, the founder of the company used to say: "Pay attention to the numbers. There will come a time when we will need them, and the numbers will determine whether we are to continue to exist or not!” More specifically, Chipboard Ltd. is strongly driven by relating financial performance indicators to the operative performance and cost measurements:

“...Chipboard Ltd. is very performance-measurement driven and relies heavily on operational measures but also on cash flows and EBITA. But still we are very much plant-driven (operational/cost-driven)...” (Head of the Group Accounting, Austria)

In particular, non-Germanic accountants link the status of accounting in the organization to the SAP system. The mobilization of the concept of Controlling is understood as a consequence of the SAP system.

"What relevance do you think management accounting has at Chipboard Ltd.?

It is extremely relevant. Yeah. And I think the concept of Controlling for me... I never ever came across it. Never! I audited all kinds of companies in the UK - a variety of companies including manufacturing companies - but I never ever came across the term Controlling. And when I came here I was like, "If you just mean management accounting..." I think it's extremely relevant at Chipboard Ltd. and I think it has a lot to do with the IT system SAP. You know that allows a very, very detailed analysis by customers, all the material breakdown...

Ok...

And Controlling again I only really connect to SAP. But it probably encompasses management accounting and a bit more. Maybe it goes into more detail...” 
Non-Germanic accountants relate the concept of Controlling and a number of idiosyncratic concepts, e.g., imputed costs, a very detailed contribution margin accounting, as well as flexible standard costing, to the SAP system (For a detailed account on idiosyncratic accounting techniques see: Heinzelmann, 2013). At the time SAP was implemented, accountants had to learn and familiarize themselves with the accounting system based on two ledgers, consisting of a set of idiosyncratic Germanic concepts. This way of conceptualizing and doing accounting is understood as a matter of the SAP system. In understanding these concepts in this way, accountants engage in repairing and maintaining their occupational identity in order to achieve biographical continuity. For non-Germanic accountants, this new way of doing accounting is linked to the system, which allows them to keep an existing identity narrative going, ensuring biographical continuity (Giddens, 1991).

Occupational identities consist of professional ideals and codes of conduct linking the profession to esoteric knowledge and societal relevance (Abbott, 1988). In organizational contexts, the construction of the good practitioner or the good management accountant is an important feature of identity work as it links ideals to the organization, as well as giving, indirectly, an indication about the professional self, the self-identity. On the one hand, non-Germanic accountants at Chipboard Ltd. stress the crucial importance of SAP knowledge and in-depth expertise either for financial or for management accounting - this is different to their professional ideal encompassing a broad and integrated accounting function. One accountant describes the "good accountant" by making reference to the skills of her German-speaking counterparts:

“...really, really in-depth knowledge of what they do... and they tend to be really, really knowledgeable in their area. And we are kind of all broad because we don't get the time to be as in-depth" (Management Accountant, UK).

On the other hand, common knowledge among accountants exists regarding the idealized role model of the good accountant, which is related to a good knowledge of processes, operations, the business model, as well as a proactive attitude. One senior controller describes a "good" controller with a comparison to a parent raising a child:

"A good controller has to treat his area of responsibility as his baby. This baby has to develop into an adult, so he must pay attention to every aspect of that development. And our manufacturing controllers are responsible for a whole plant, which means for all processes, procedures, results, and so on and so forth. Thus, he naturally knows all the processes and procedures. His task is to identify and establish as well as to implement optimization arrangements" (Senior Controller, Austria).

In the same vein, an Austrian plant controller notes:

"I had a good teacher who said a good controller has to reek of oil once a week, and I always tried to do that. Admittedly, that has lately not been possible anymore. It's a question of time. When there is something to discuss, I usually try to have a face-to-face meeting with the person in charge. Either I go out (to the manufacturing unit) or we meet at my office. When I'm out I always get new input. By just chatting over coffee, you see and hear something new” (Plant Controller, Austria).

The idea that "a good controller has to reek of oil once a week" demonstrates the importance of both understanding the business and being involved in the processes, but the communicative aspect of the job is also seen as crucial. Among the accountants, there is an awareness of a lack of closeness to the operations and the business. Specifically, one senior accountant complains about the gap between the ideal and the reality:

"It is just more important to a management accountant to have a better understanding of the business and the processes you are working in. And I know that some of our staff in accounts [accounting department] here don't actually know the products that we produce because they work on service sales ledgers and gather the money and deal with the customers. They don't know anything about the types of products we produce and about the process goes into that..." (Financial Controller, UK).

Despite of the fact that Chipboard Ltd. is not mobilizing the role model of a business partner or business analyst (Burns and Baldvinsdottir, 2005), accountants make the idealized roles ascribed by the professions part of their picture of the "good accountant." In other words, the role models of the business partner, described as the real-life accountant (CIMA) or the sparring partner (Controller Akademie), finds its way into the idealized descriptions of the professional selves at Chipboard Ltd. 


\section{Major findings and concluding comments}

This paper finds that occupational identities of management accountants are exposed to various forms of identity regulation, upon which accountants conduct identity work. As opposed to the prior literature in management, which has mainly noted a change towards the business partner role, this paper finds a "messy role" prevalent for accountants - a role which is characterized and dominated by tight controls of practices emerging from the IT system, and a high number of standards and templates.

The paper shows how different professional bodies attempt to prescribe role models for their accountants. In the context of management accounting, the dominant discourse is characterized by drawing the role of the business partner to the fore. However, as it has been shown in the paper, different professional bodies put more emphasis on slightly different idealized professional descriptions of self.

For instance, the Institute of Chartered Accountants of England and Wales (ICAEW) stresses the importance of the role model labelled finance leader. The finance leader is in line with ICAEW's jurisdiction encompassing the entire field of accountancy in the public, legal, and workplace arenas, as opposed to the Chartered Institute of Management Accountants (CIMA) that exhibits full jurisdiction only in management accounting and advocates for the role of the real-life accountant, juxtaposed with the role of the auditor. In addition, the role model provided by Germanic bodies, namely the Controller's Academy and the Austrian Controller Institute, is labeled the sparring partner role. These German-speaking management accounting bodies in particular, since they only possess workplace jurisdiction for management accounting, pinpoint the crucial role controllers play in decision-making. In light of the literature, all management accounting bodies focus on distinguishing themselves from "ordinary" accounting bodies by relying on the business partner and business analyst role. This subjects accounting to differentiate "different” accountants. Specifically, German-speaking accounting relies heavily on the distinction between financial accounting and management accounting in terms of systems, roles, etc.

Within Chipboard Ltd., identity regulation does not draw directly on the role models provided by professional bodies. However, the distinction between financial and management accounting is unquestioned and taken for granted and even reinforced by the strong focus on the SAP system, which uses two separate systems for financial and management accounting, namely the FI- and the CO-module. Management accounting became "reduced" to technicalities through the strong system emphasis. Chipboard Ltd. combines socio-ideological and technocratic controls to direct management accountants' identities. Socio-ideological control is characterized by the use of the Germanic term Controlling across the group regardless of accounting traditions and a strong accounting group setting the agenda in accounting. Additionally, the accounting group developed a significant number of standards, rules, guidelines, and templates which are commonly linked to the SAP system. The latter allowed the accounting group to implement a set of idiosyncratic Germanic accounting techniques to its non-Germanic subsidiaries.

The combination of socio-ideological and technocratic controls creates a strong and highly regulated, repressive framework for accountants to engage in identity work. In order to achieve biographical continuity, management accountants make sense of the use of the concept of Controlling as well as the idiosyncratic German-speaking techniques by understanding them as a consequence of working with the SAP system. Furthermore, the "good management accountant” is constructed in line with the business partner role put forward by professional bodies. There is a strong disconnect between the actual practices and this role. Upholding this idealized description of self enables accountants to keep their occupational identity going, safeguarding biographical continuity (Giddens, 1991). The culture of highly regulated practices through the centralization of decision-making, rules, guidelines, templates, and a predominant SAP system limits the freedom to act and judge as a professional, as an accountant.

The paper has addressed questions about how identity regulation and work take place in an organizational setting. By doing so, the paper contributes to the extant literature in accounting by shedding light on identity regulation and work. Specifically, it contributes firstly to the discussions revolving around the socialization of accountants, providing further evidence for the argument that organizational socialization dominates professional socialization by drawing on a case study of management accounting. Thus, the paper adds a case from management accounting to the literature which is dominated by empirical studies on the big four accounting firms.

Secondly, I provide additional evidence for the importance of different institutional environments shaping the way in which accounting is enacted, which shapes accountants' identities (Ahrens and Chapman, 2000), demonstrating that education and professional ideals can impact how guidelines are constructed and what is taken for granted or not, which in turn changes practices and occupational identities. I portray an organization engaged heavily in identity regulation by drawing on a combination of socio-ideological and technocratic forms of control in order to direct accounting practices. Morales and Lambert (2013) show the dilemma of accountants in adopting a more business- 
inclined role, which paradoxically produces more dirty work, that is, work which is not in line with the idealized role of the business partner. The management accountants at Chipboard Ltd. uphold and include the idealized description of self (i.e., the business partner role) in the role model when describing and constructing the "good management accountant.” The decoupling between the idealized role and the actual practice is explained by understanding accounting practices as a matter of the SAP system.

Thirdly, the roles and tasks linked to management accountants in Chipboard Ltd. are focused around the system and driven by operational concerns, but at the same time, the importance of accounting for decision-making is emphasized. In general, management accounting is constructed to be very important and more important than engineering and financial accounting. In particular, the decision-usefulness of management accounting information is highlighted. In terms of professional completion, the case of Chipboard Ltd. is interesting as accounting gains significance in contrast to other professions while having, at the same time, less flexibility for professional actions and judgment.

Finally, the paper makes an important contribution to the literature on identity as it demonstrates that the concept Alvesson and Willmott (2002) developed is also suitable to investigate identity regulation on a micro level. By drawing additionally on different forms of control, namely the alignment between technocratic and socio-ideological forms of control, the paper refines the investigation of occupational identity. Furthermore, Gidden's (1991) vocabulary, especially the notion of biographical continuity, presents an important extension to prior identity studies. Specifically, in accounting where professional and organizational socialization are crucial, biographical continuity can help to explain why accountants on the one hand draw on the professional idealized role and on the other hand engage in other work duties.

To conclude, occupational identities of management accountants are strongly guided by the actual accounting practices that are profoundly regulated by organizations, where the combination of IT systems along with normative and social elements play an important role. 


\section{References}

Ahrens, T. \& Chapman, C.S. 2000. Occupational identity of management accountants in Britain and Germany. European Accounting Review, 9(4): 477-498.

Alvesson, M. 2010. Self-doubters, strugglers, storytellers, surfers and others: Images of self-identities in organization studies. Human Relations, 63:193-217.

Alvesson, M., Ashcraft K. \& Thomas R. 2008. Identity matters: reflections on the construction of identity scholarship in organization studies. Organization, 15: 5-28.

Alvesson, M. \& Kärreman, D. 2004. Interfaces of control. Technocratic and socio-ideological control in a global management consultancy firm. Accounting, Organizations and Society, 29(3-4): 423-444.

Alvesson, M. \& Sveningsson, S. 2003. Good visions, bad micro-management and ugly ambiguity: Contradictions of (non-)leadership in a knowledge-intensive organization. Organization Studies, 24: 961-988.

Anderson-Gough, F., Grey, C. \& Robson, K. 2005."Helping them to forget..": the organizational embedding of gender relations in public audit firms. Accounting, Organizations and Society, 30(5): 469-490.

Armstrong, P. 1985. Changing management control strategies: The role of competition between accountancy and other organisational professions. Accounting, Organizations and Society, 10(2): 129-148.

Armstrong, P. 1987. The rise of accounting controls in British capitalist enterprises. Accounting, Organizations and Society, 12: 415-436.

Ashcraft, K.L. 2013. The Glass Slipper:“Incorporating” Occupational Identity in Management Studies. Academy of Management Review, 38: 6-31.

Azan, W. \& Bollecker, M. 2011. Management control competencies and ERP: an empirical analysis in France. Journal of Modelling in Management, 6:178-199.

Becker, S.D., Jagalla, T. \& Skærbæk, P. The translation of accrual accounting and budgeting and the reconfiguration of public sector accountants' identities. Critical Perspectives on Accounting. in Press.

Burns, J. \&Baldvinsdottir, G. 2005. An institutional perspective of accountants' new roles- the interplay of contradictions and praxis. European Accounting Review, 14: 725-757.

Burns, J. \& Baldvinsdottir, G. 2007. The changing role of management accountants. In: Hopper, T., Northcott, D. \& Scapens, R.W., editors. Issues in Management Accounting. Harlow: Prentice Hall, 117-132.

Carter, C. \& Crowther, D. 2000. Unravelling a profession: the case of engineers in a British regional electricity company. Critical Perspectives on Accounting, 11: 23-49.

Coffey, A.J. 1993. Double entry: The professional and organizational socialization of graduate accountants. Unpublished doctoral thesis. University of Wales. Cardiff: 1993.

Coffey, A.J. 1994. Timing is Everything'; Graduate Accountants, Time and Organizational Commitment. Sociology. 28: 943.

Cooper, D.J. \& Robson, K. 2006. Accounting, professions and regulation: Locating the sites of professionalization. Accounting, Organizations and Society. 31: 415-444.

Ezzamel, M. \& Burns, J. 2005. Professional competition, economic value added and management control strategies. Organization Studies. 26: 755.

Friedman, A.L. \& Lyne, S.R. 2001. The beancounter stereotype: towards a general model of stereotype generation. Critical Perspectives on Accounting. 12: 423-451.

Giddens, A. 1991. Modernity and Self-Identity: Self and Society in the Late Modern Age. Cambridge: Polity Press.

Goretzki, L., Strauss, E. \& Weber, J. 2013. An institutional perspective on the changes in management accountants' professional role. Management Accounting Research. 24: 41-63.

Granlund, M. \& Lukka, K. 1989. Towards increasing business orientation: Finnish management accountants in a changing cultural context. Management Accounting Research. 9: 185-211.

Hanlon, G. 1998. Professionalism as Enterprise: Service Class Politics and the Redefinition of Professionalism. Sociology. 32: 43-63.

Haynes, K. 2006. Linking narrative and identity construction: using autobiography in accounting research. Critical Perspectives on Accounting. 17: 399-418.

Heinzelmann, R. 2013. Diverging identities and professions in European management accounting. Unpublished doctoral thesis. University of Innsbruck. Innsbruck: 1-242.

Heinzelmann, R. 2013. Standardization in management accounting: A field study of SAP and its influence on accounting. $36^{\text {th }}$ EAA Annual Congress, Paris: 2013.

IGC. Controlling-Prozessmodell. Ein Leitfaden für die Beschreibung und Gestaltung von Controlling-Prozessen. Freiburg: HAUFE; 2011.

Kurunmäki, L. 2004. A hybrid profession--the acquisition of management accounting expertise by medical professionals. Accounting, Organizations and Society. 29: 327-347. 
Lambert, C. \& Sponem, S. 2011. Roles, authority and involvement of the management accounting function: a multiple case-study perspective. European Acccounting Review. 1-25.

Lamont, M. 1992. Money, morals, and manners: The culture of the French and American upper-middle class. Chicago: University of Chicago Press; 1992.

Llewellyn, S. 1998. Boundary work: Costing and caring in the social services. Accounting, Organizations and Society. 23: 23-47.

Messner, M., Becker, A., Schäffer, U. \& Binder, C. 2008. Legitimacy and identity in Germanic management accounting research. European Accounting Review. 17: 129-159.

Mouritsen, J. 1996. Five aspects of accounting departments' work. Management Accounting Research. 7: $283-303$.

Mueller, F. \& Carter, C. 2007. 'We are all managers now': Managerialism and professional engineering in UK electricity utilities. Accounting, Organizations and Society. 32: 181-195.

Ravasi, D. \& Canato, A. 2013. How Do I Know Who You Think You Are? A Review of Research Methods on Organizational Identity. International Journal of Management Reviews.

Simon, H.A., Guetzkow, H., Kozmetsky, G. \& Tyndall, G. 1954. Centralization vs. decentralization in organizing the controller's department: A research study and report. New York: Controllership Foundation; 1954.

Simons, D. \& Weißenberger, B.E. 2008. Die Konvergenz von externem und internem Rechnungswesen. Betriebswirtschaftliche Forschung und Praxis. 60: 137-62.

Trapp, R. 2012. Konvergenz des internen und externen Rechnungswesens. Zeitschrift für Betriebswirtschaft. 82: 9691008.

Vaivio, J. 1999. Examining “the quantified customer”. Accounting, Organizations and Society. 24: 689-715.

Vaivio, J. 2004. Mobilizing local knowledge with 'Provocative'non-financial measures. European Accounting Review. 13: $39-71$.

Whittington, R. \& Whipp, R. 1992. Professional ideology and marketing implementation. European Journal of Marketing. 26: 52-63.

Zirkler, B. 2002. Führungsorientiertes US-amerikanisches Management Accounting. Wiesbaden: Gabler; 2002. 


\section{Appendix}

\begin{tabular}{|c|c|c|c|}
\hline \multicolumn{4}{|c|}{ Empirical material } \\
\hline \multicolumn{4}{|c|}{ Case Study } \\
\hline Interviews & Country & Length & Date \\
\hline Financial director & Austria & 00:59:21 & 24.06 .2010 \\
\hline Head of accounting group & Austria & 01:04:48 & 24.06 .2010 \\
\hline $\begin{array}{l}\text { Head of the management accounting } \\
\text { group }\end{array}$ & Austria & $01: 11: 26$ & 24.06 .2010 \\
\hline Senior management accountant & Austria & $01: 15: 30$ & 24.06 .2010 \\
\hline Plant controller & Austria & 01:02:03 & 24.06 .2010 \\
\hline Plant controller & Austria & 01:03:45 & 24.06 .2010 \\
\hline Plant controller & Austria & 00:45:35 & 24.06 .2010 \\
\hline Financial director & UK & 01:07:22 & 14.09 .2010 \\
\hline Technical director & UK & 00:58:06 & 14.09 .2010 \\
\hline Financial controller & UK & $00: 56: 56$ & 14.09.2010 \\
\hline Management accountant & UK & 00:37:09 & 14.09 .2010 \\
\hline Management accountant & UK & $00: 46: 50$ & 14.09 .2010 \\
\hline Financial director & France & $00: 58: 28$ & 18.11 .2010 \\
\hline Head of management accounting & France & $01: 21: 24$ & 18.11 .2010 \\
\hline Plant controller & France & 00:46:08 & 18.11.2010 \\
\hline Plant controller & France & $00: 36: 07$ & 18.11 .2010 \\
\hline Head of maintenance & France & $00: 22: 59$ & 18.11 .2010 \\
\hline Head of quality management & France & $00: 24: 33$ & 18.11.2010 \\
\hline \multicolumn{4}{|l|}{ Other materials } \\
\hline \multicolumn{4}{|c|}{$\begin{array}{l}\text {-Handbook of Management Accounting (available in German, English) } \\
\text {-Mission statements, internal documents, i.e. on the role of management accountants, their } \\
\text { duties, presentations etc. } \\
\text {-Public available information }\end{array}$} \\
\hline \multicolumn{4}{|c|}{ Professional bodies } \\
\hline \multicolumn{4}{|l|}{ Interviews } \\
\hline Director of education, CA & Germany & 01:53:00 & 07.10 .2010 \\
\hline CEO, CA & Germany & 01:53:00 & 07.10 .2010 \\
\hline CEO \& Director of education, ÖCI & Austria & $01: 25: 17$ & 14.10 .2010 \\
\hline Director of education, CIMA & UK & $01: 15: 47$ & 02.12 .2010 \\
\hline Director of Research, ICAEW & UK & 01:01:15 & 01.10 .2010 \\
\hline Professor of accounting & UK & $00: 41: 57$ & 01.12 .2010 \\
\hline Professor emeritus in accounting & UK & $00: 53: 17$ & 03.12 .2010 \\
\hline \multicolumn{4}{|l|}{ Other materials } \\
\hline \multicolumn{4}{|c|}{$\begin{array}{l}\text {-Trainings scheme, CIMA } \\
\text { - CIMA's history, book } \\
\text {-Diverse advertising materials, CIMA } \\
\text {-Training scheme, ICAEW } \\
\text {-Diverse advertising material, ICAEW } \\
\text {-Strategic document on the finance function } \\
\text {-Training scheme five stage program CA \& ÖCI } \\
\text {-Educational program, CA \& ÖCI } \\
\text {-Diverse advertising materials, CA \& ÖCI }\end{array}$} \\
\hline
\end{tabular}

